\title{
Hydrocarbon Prospectivity in Central Part of Tripura, India, Using an Integrated Approach
}

\author{
Jwngsar Brahma ${ }^{1}$, Anirbid Sircar ${ }^{1}$, G. P. Karmakar ${ }^{1}$ \\ ${ }^{1}$ Pandit Deendayal Petroleum University, Raisan Village, Gandhinagar, Gujarat, India \\ Correspondence: Anirbid Sircar, Pandit Deendayal Petroleum University, Raisan Village, Gandhinagar, \\ Pin-382007 Gujarat, India. E-mail: michiann@optonline.net
}

Received: July 3, 2013 Accepted: August 2, 2013 Online Published: August 8, 2013

doi:10.5539/jgg.v5n3p116 URL: http://dx.doi.org/10.5539/jgg.v5n3p116

\begin{abstract}
In this study an attempt has been made to evaluate the hydrocarbon prospectivity of Central Tripura. The geological factors, surface exposures, geochemical anomalies, seismic expressions have been studied and were correlated with distribution pattern of gas fields in Bangladesh. Discoveries of oil and gas in and around of the study area have been studied and prospects have been analyzed in light of various geological and geophysical risks associated with them. The exploration efforts which were mostly confined to the synclinal areas are now gradually getting shifting towards the anticlines. The integrated study proposed in this study can help us to prepare a road map for exploration in the north east part of India.
\end{abstract}

Keywords: atharamura, tulamura, baramura, anticline, syncline, hydrocarbon, bhuban, tipam

\section{Introduction}

The Tripura region is situated in the north - eastern sector of India, and is surrounded by the territories of Bangladesh and Burma, except in the north - eastern part, which is bordered by the Indian states of Assam and Manipur. Geographically, it is bounded by the latitudes $22^{\circ} 00^{\prime} \mathrm{N}$ and $24^{\circ} 30^{\prime} \mathrm{N}$ and the longitudes $91^{\circ} 10^{\prime} \mathrm{E}$ and $93^{\circ} 30^{\prime} \mathrm{E}$. The central part of Tripura can be structurally divided into four parts: Atharamura anticline, northern part of the Tulamura anticline and parts of two synclines, namely, Khowai and Dolai, situated at the western and eastern side, of the Atharamura anticline respectively as shown in the Figure1 (Ganguly, 1993). The Atharamura anticline, the longest (about $100 \mathrm{~km}$ ) and largest of all the anticlines exposed in Tripura fold belt constitutes almost half of the study area. It extends for more than $25 \mathrm{~km}$ in Bangladesh towards south. The Tulamura anticline situated in the southern most part of the study area is disposed enechelon to the hydrocarbon bearing Baramura anticline (Figure 2). The major part of this anticline goes to Bangladesh towards its south. Exploratory efforts so far have brought out a number of commercially viable gas fields in and around the study area such as Baramura, Rokhia, Agartala Dome and Gojalia in the western part, Moulavi Bazar, Rashidpur in the north and oil shows in Haraganj to its east. A broad similarity in source, maturation, migration and entrapment coincidence between the Bangladesh and Tripura sub basin is remarkable from the foregoing discussion. Bangladesh has approximately $25 \mathrm{TCF}$ of gas initially in place and $15.52 \mathrm{TCF}$ of recoverable reserves. The success ratio of Bangladesh is 3.1:1. The presence of thick sequence of reservoir quality sandstone coupled with organic rich shale, and of different kinds of traps including broad anticlinal structure, makes the basin highly prospective for hydrocarbon exploration (Imam \& Hassain, 2002). A common hydrocarbon generation center could not be ruled out, though the synclinal troughs in Tripura are capable of generating and charging the structure. However, reservoir facies of Bangladesh is better developed. It is observed that the average Helium porosity is estimated as $19 \%$ and varies within the range from $5 \%$ to $28 \%$ (Islam, 2009). Hileum porosity reduces with increasing depth due to the detrital grain contacts are turned from point to long contact in Bangladesh side and the volumetric amount of quartz, carbonate, pyrite and clay cement increases and partially occlude intergranular pore space. The correlation between Helium porosity and horizontal permeability is positive and the horizontal permeability varies from $0.5 \mathrm{mD}$ to $490 \mathrm{mD}$ with an average $200 \mathrm{mD}$ (Islam, 2009). Although the reservoir does not contain significant volume of carbonate but the inverse relationship of the porosity and permeability with cement remains relatively steady state throughout the reservoir in Bangladesh side. The collision of Indian plate with Burmese plate and Tibetan plate, results in a major switch in sedimentation pattern over the Bengal Basin during the Middle Eocene to Early Miocene. During this time the was rapid influx of clastic sediments into the basin 
from the Himalayas to the north and the Indo - Burma Range to the east and this was followed by an increase in the rate of subsidence of the basin. In the Bengal Basin sedimentation is thought to have taken place in five distinct phases namely: Permo - Carboniferous to early Cretaceous; Cretaceous - Mid Eocene; Mid Eocene Early Miocene; Early Miocene - Mid Pliocene; and Mid Pliocene - Quaternary. Moreover in Bengal Basin the characterization of reservoir rocks are fine to medium grained sandstone, sandstone - siltstone interbeds and laminated siltstone. Surma Groups (Bokabil and Bhuban Formation) sediments are deposited in a deltaic setting (Holtrop \& Keizer, 1970; Johnson \& Alam, 1991) and it is also observed that quartz (mostly monocrystalline), renging from $44 \%$ to $54 \%$ dominates the dertrital mineralogy in Bengal Basin (Islam, 2009). A number of Middle Bhuban sand facies in Tripura are heterogeneous and lenticular in nature. In spite of that the large anticlines of Tripura with considerable amplitude forms a potential trap for housing sizable amount of hydrocarbons.

In light of the above, we tried to describe the tectonic similarity between Central Tripura and Bangladesh. In this study, hydrocarbon prospectivity of the area has been analyzed using various geological and geophysical studies carried out independently. An attempt has been made to integrate all these studies to derive a meaningful geological model of the area. The outcome of such study is aimed at identifying various plays within this area and to minimize the risk of exploration targets. A conceptualized future work programme has also been envisaged in order to upgrade the value of exploration plays.

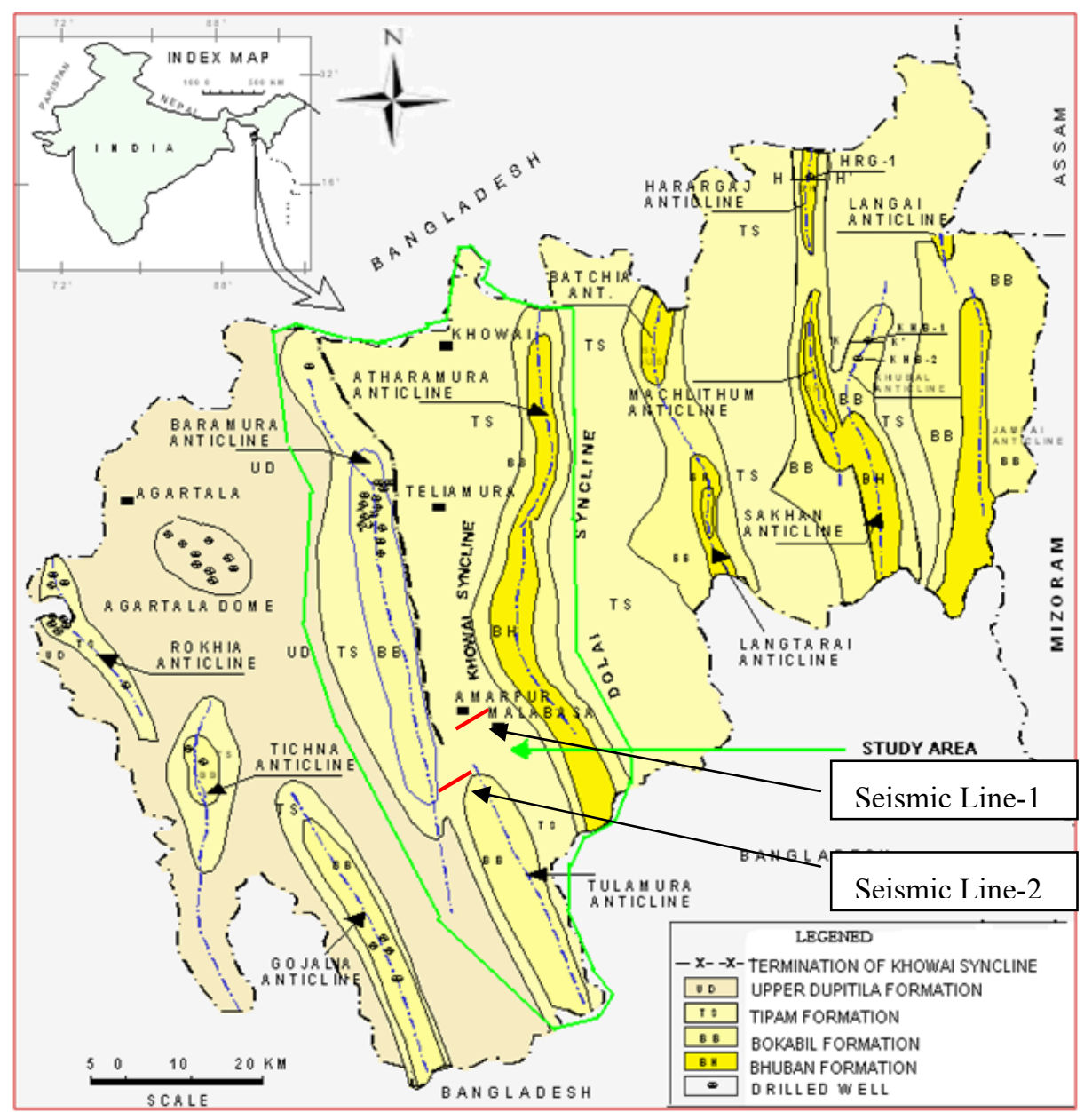

Figure 1. Anticlines and synclines in and round Atharamura, Baramur and Tulamura anticlines. Map depicts the structural position of the study area (Ganguly, 1993) 


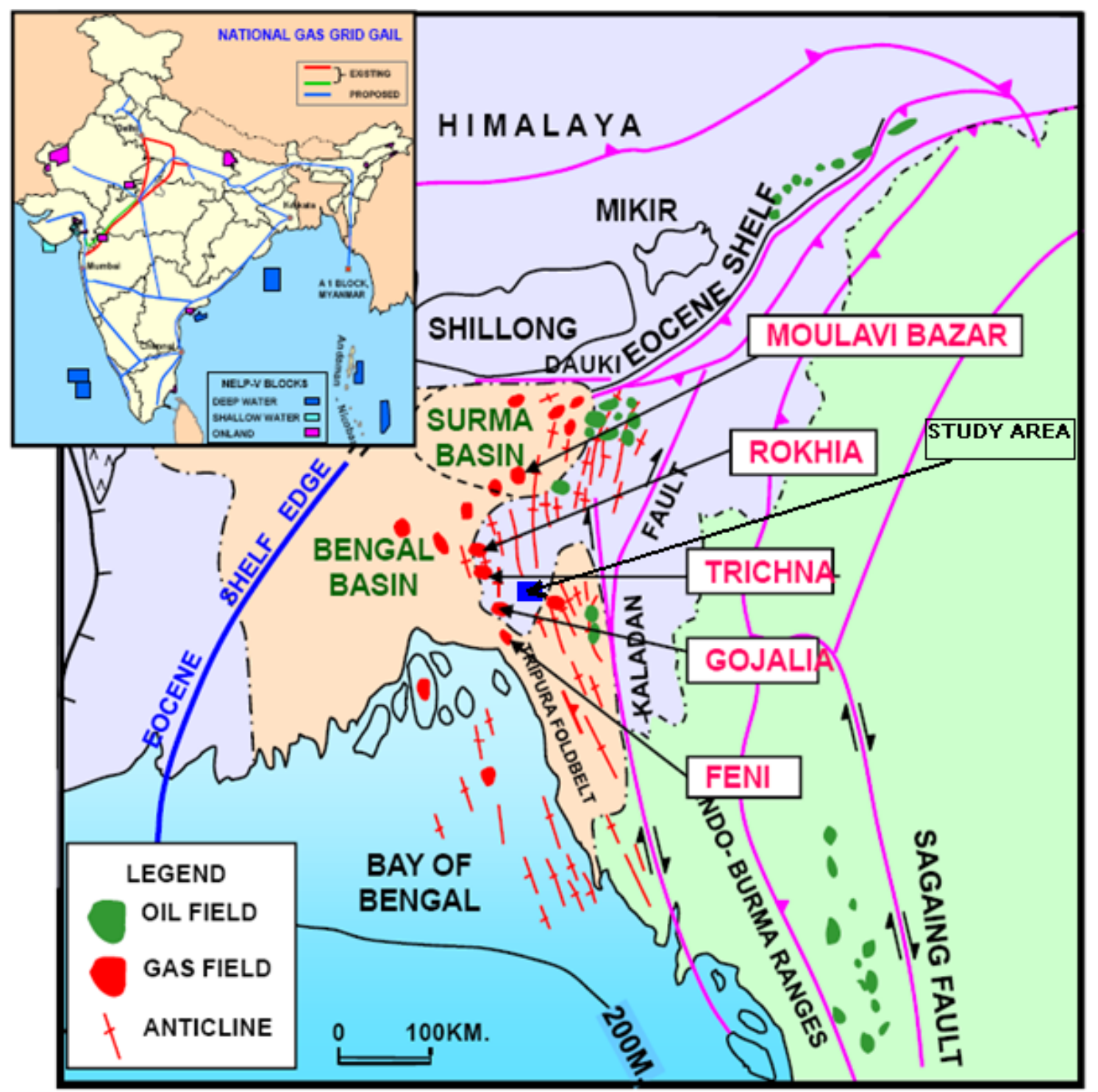

Figure 2. Hydrocarbon discoveries in and around the study area (Curial et al., 2002)

\section{Tectonic Framework and Basin Evoluation of Bengal Basin}

Beyond the geographical boundaries, the sub - basins of Tripura and Bangladesh form a single geological entity representing a part of the basinal facies of Assam - Arakan basin, which came into existence during late Cretaceous collision and concomitant subduction of the Indian plate margin below Burmese plate. This combined geological unit can be subdivided into three broad tectonic elements: Sylhet through to the north, Tripura - Chittagong to the east and southeast and Pathuakhali depression to the south, beyond which the basin opens up in the Bay of Bengal (Shamsuddin et al., 1997). The basin exhibits a general N-S trend, designated as Chittagong strike, which abuts against the Hail Hakalula lineaments in the northwest within the Bangladesh plains. Surma basin defines the northernmost extension of the fold belt; while the more prominent Bengal basin defines the western and southern extension of the belt .The uplifted Tripura fold belt had undergone severe folding, faulting and thrusting during the different phases of post collision orogenies, the intensity of which increases eastward (Kunte, 1989). Tectonically, this fold belt comprises a series of sub-parallel elongated enechelon doubly plunging anticlines separated by wide and flat synclines (Khar et al., 1984). The anticlines are usually bounded by longitudinal reverse faults on one or either limbs, which disappear towards the plunge of the folds (Kunte, 1989). The young cross faults and oblique faults of multiple alignments with strike slip component offset the longitudinal faults and the fold axis (Khar et al., 1984). 
The oblique subduction of the Indian plate under the Chinese plate stamped structurally the eastern portion of the Bengal Basin and the eastern part of Bangladesh: this region is dominated by the distal, compressional Indo-Burman Fold Belt, which moved as from Early Miocene time towards west, reaching Bangladesh territory as from Late Miocene/Early Pliocene times onwards (Alam et al., 2003). The Sylhet Basin of Bangladesh (sub basin of the Bengal Basin) contains very thick (up to $22 \mathrm{~km}$ ) Tertiary stratigraphic succession. The Sylhet succession consists mainly sandstone and mudstone and is divided into the Jaintia (Paleocene - late Eocene), Barail (late Eocene - early Miocene), Surma (middle - late Miocene), Tipam (late Miocene - Pliocene) and Dupitila (Pliocene - Pleistocene), in ascending order (Hossain et al., 2009). The total organic carbon (TOC) content varies from $0.11 \%$ to $1.56 \%$ in the Sylhet succession systematically with sedimentation rate, with low TOC caused by clastic dilution by high sedimentation rates arising from rapid uplift and erosion of the Himalaya (Hossain et al., 2009). The Sylhet succession has three phases depositional environments. The deposition occurred completely in seawater dominated oxic conditions with abundant input of terrestrial higher plants, including angiosperms during first phase (middle Eocene to early Miocene). The Freshwater anoxic conditions along with a small seawater influence according to eustasic sea level changes, with diluted organic matter derived from phytoplankton and a lesser influence from terrestrial higher plants during the second phase (middle to late Miocene). Oxygen poor freshwater conditions prevailed in the third phase (post - late Miocene).

The Tripura fold belt has undergone four stages of basin development-synrift and pre-collision, drifting sediments, early collision and late collision.

i. The synrift and precollison is known only from the western margin and northern margin (Dauki Fault area). The first stage rests unconformably on a metamorphic basement, corresponds to the pre-breakup stage, and consists of interbedded coarse-grained sandstone and coal/carbonaceous shales. The unconformity seaparting the breakup sediments from the post breakup sediments is represented by Lower Cretaceous Rajmahal trap (Curiale et al., 2002).

ii. The drift sediments consist of Cretaceous Eocene deposits overlying Upper Paleozoic and Mesozoic Gondwana graben deposits of largely continental origin (Alam, 1989).

iii. Early collision sedimentation was contemporaneous with the beginning of continental collision (Oligocene-late Miocene), when initial uplift of the Himalayan and Indo-Burmese ranges occurred. Sediments deposited at this time in the eastern fold belt and Surma range in thickness from 10-15 km and were deposited in deltaic sediments, with marine incursions mainly in the Oligocene-Late Miocene (Curiale et al., 2002).

iv. The late collision sediments include the Upper Bhuban and Bokabil units overlain by Tipam and Dupitila units. The stage is represented by sedimentation contemporaneous with the major phase of continental collision (Curiale et al., 2002). Deposition occurred in fluvial deltaic to estuarine environments. The tectonics and geological setting of the study area have been greatly influenced by late collision phase.

\section{Stratigraphic Succession}

The Tripura sub - basin is constituted by a huge Tertiary sedimentary sequence of Post Cretaceous to Pleistocene age (Momin et al., 1999). The generalized stratigraphic section in the study area is given in Figure 3. All the wells drilled so far in Tripura have penetrated only up to Surma Group of rocks. The Lower to Middle Miocene Surma Group, consisting of the Bhuban Formation and the overlying Bokabil Formation was deposited during repeated transgressions and regressions. These widespread units together reach more than $4500 \mathrm{~m}$ thickness in the Tripura fold belt and the deeper part of the Bengal basin. The sequence appears to thicken towards south and east and appear to have its depocentre in Mizoram (Chakravorty et al., 2011). Out of the three units within the Bhuban Formation, the lowermost and uppermost are mainly siltstones and fine-grained sandstone, alternating with mudrock, whereas middle unit is composed of silty and sandy mudstone. The Bokabil formation generally consists of alternating mudstone, siltstone, and fine to medium-grained sandstones. The middle part of the Bokabil is more arenaceous and forms natural gas reservoirs in the Tripura as well as in Bengal basin (Uddin \& Lundberg, 1999). 


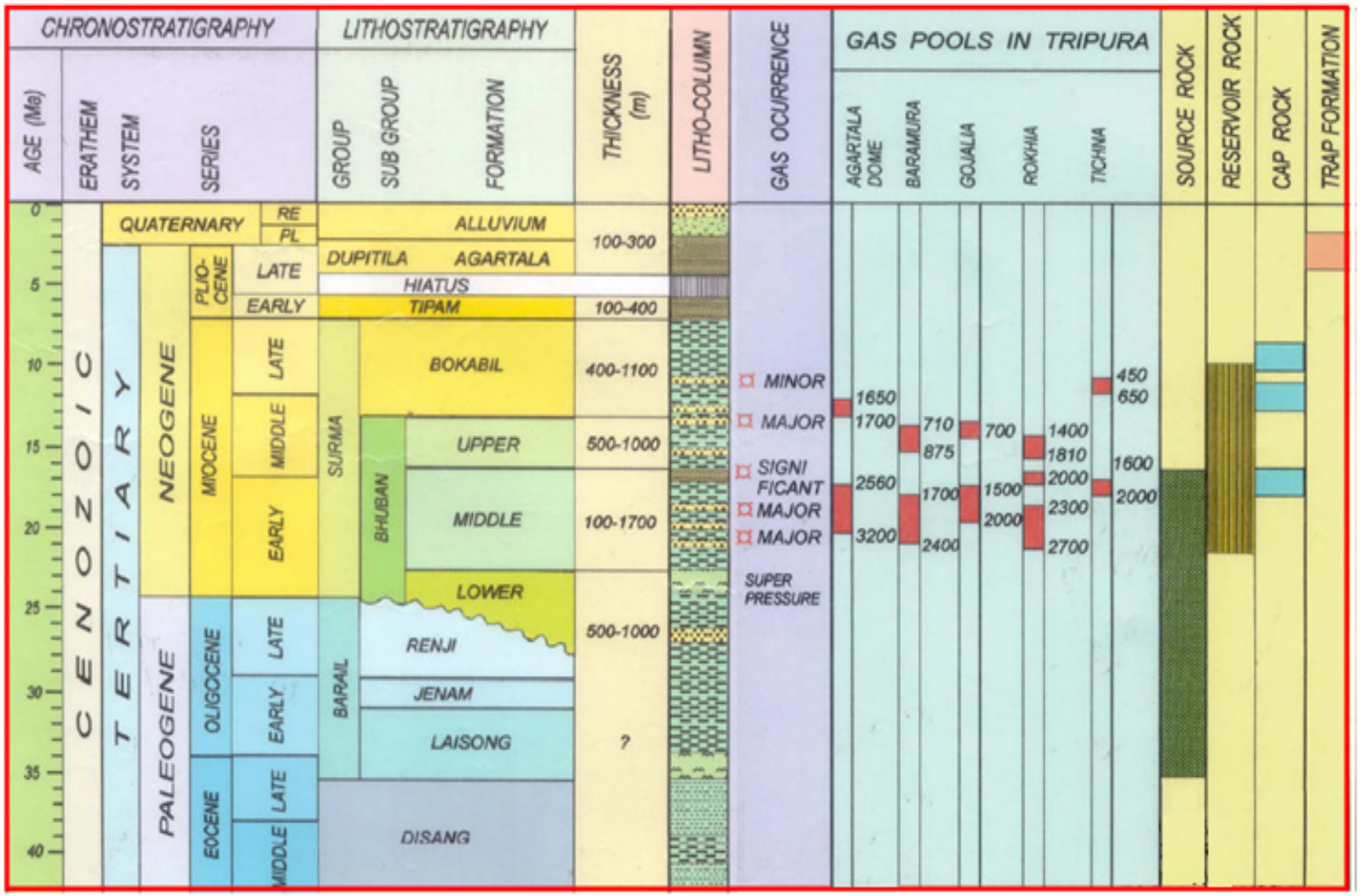

Figure 3. Stratigraphy and petroleum system of Tripura, Assam-Arakan basin (The red intervals highlighted above reflect the gross intervals within which multiple pays are producing. The range of pays varies between 40-80 meters. (After Akram et al., 2004)). The gross thickness of gas pools are shown with red rectangles

\section{Paleogeography and Paleoenvironment}

Deltaic to shallow marine depositional settings have been interpreted for Neogene Surma Group of rocks, exposed throughout the south - east fold belt of Bengal basin. Based on the earlier studies in field outcrop over Sitapahar anticline, Rangamati area, and in the Mirinja anticline it has been proposed that the Surma Group succession represent overall basin ward progradation from deep marine to coastal marine depositional settings (Gani \& Alam, 1999). Comparable deep sea clastics with thicker intervals of sandstone turbidities, contained within a submarine canyon are present in the Mirinja anticline (Das Gupta et al., 1991).

Detailed paleoecological study of borehole samples are carried out from selected number of wells drilled in Rokhia, Tichna, Gojalia, Agartala Dome, Pathalia, Baramura and Haraganj structure in Tripura area. This reveals that various types of paleoenvironments of deposition prevailed during the past. These include- fluvial, coastal, upper deltaic, lower deltaic, tidal shallow marine, inner neritic and inner-middle neritic environments. This study also indicated that marine transgressions occurred during the deposition of sequences of Lower Bhuban, Middle Bhuban and Bokabil along with in between regressions during the deposition of the sequences of Middle Bhuban, Upper Bhuban and Bokabil. Tipam formation shows fluvial character (Nanjundaswamy et al., 1993).

Paleogeographic maps (Figure 4) prepared for the various depths at the equivalent palynozones depict surface manifestation of the distribution of various realms of deposition at a given palynostratigraphic/lithostratigraphic level. The vertical thickness of sediments in each of these environments varies both vertically and laterally thus resulting in various shapes in the geometry of the sediments. 

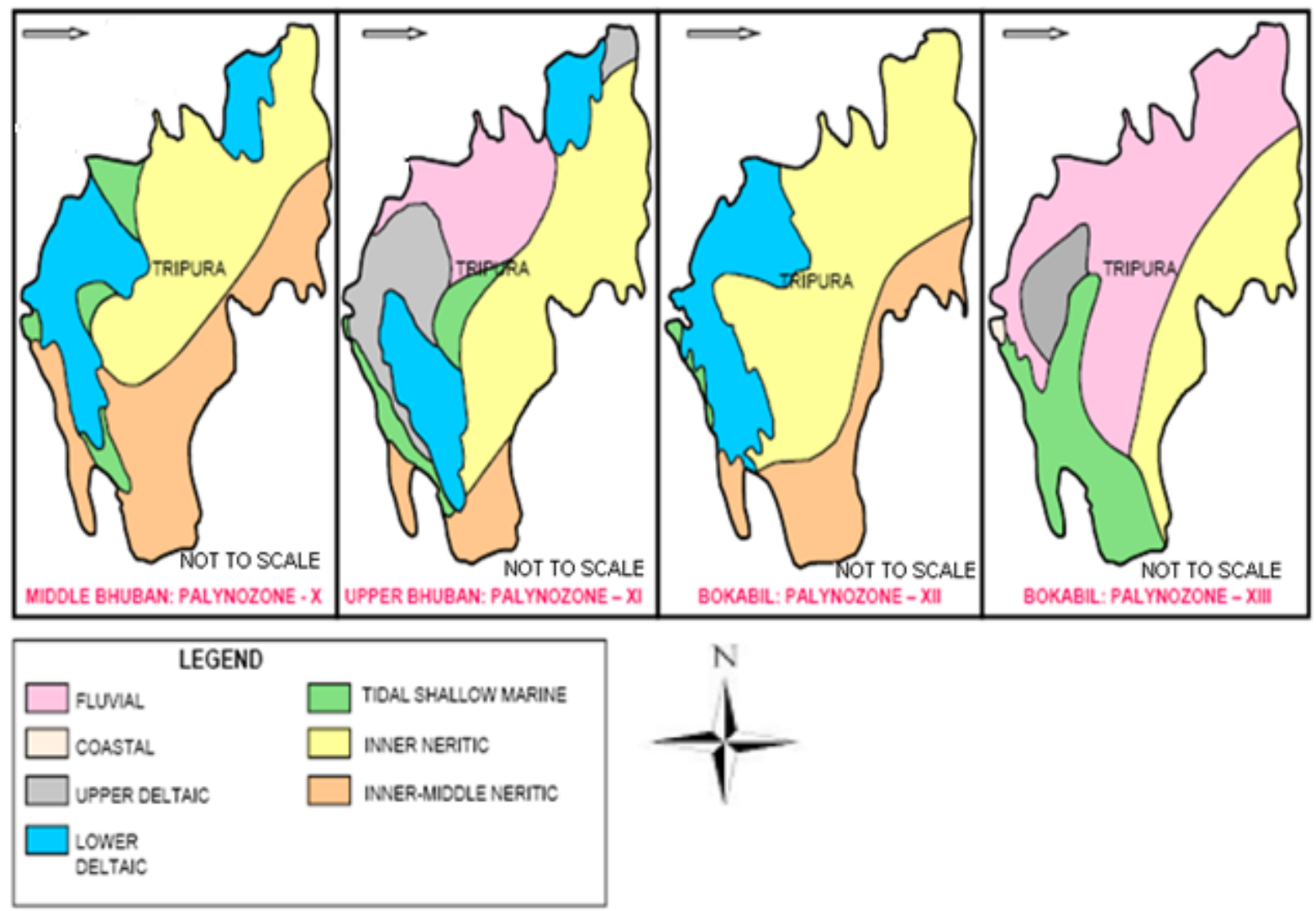

Figure 4. Paleogeography maps of the Tripura area (after Nanjundaswamy et al., 1993)

\section{Hydrocarbon Potential}

\subsection{Hydrocarbon Province of Bangladesh}

Till now more than twenty gas and gas-condensate fields have been discovered in Bangladesh (Khan et al., 1999), thereby establishing it as one of potential hydrocarbon province (Figure 5). Apart from innumerable gas shows, oil seepages are reported from a number of places. There are seven gas-condensate fields discovered in Bangladesh. About $1,325 \mathrm{bbl}$ of condensate is being produced everyday and the total recoverable reserve is 64.69 million bbl. Beanibazar (1.82 million bbl), Kailashtila (26.9 million bbl), Jalalabad (15.75 million bbl), Rashidpur (4.0 million bbl), Feni (8.23 million bbl), Bakhrabad (2.08 million bbl), Titas (1.65 million bbl), Sylhet (0.38 million bbl), Fenchuganj (0.52 million bbl), Belabo (0.31 million bbl), Meghna ( 0.21 million bbl) and Habiganj (0.08 million bbl) are significant fields. Major condensate producing fields are Kailashtila, Rashidpur, Jalalabad, Habiganj and Beanibazar. The recently discovered Bibiyana and Maulvi Bazar gas fields are considered to be two major gas-condensate fields and these have a considerable recoverable condensate reserve. But the condensate reserves of these two fields are now at the stage of appraisal, and therefore, not included in the total reserve estimation. Reservoirs are mainly in fluvial and deltaic sandstone of Miocene and Pliocene age (Upper Bhuban, Bokabil and Tipam Formations/Group), occurring commonly in multiple stacked layers. The producing depth ranges in between $1100 \mathrm{~m}$ to $3000 \mathrm{~m}$ with individual reservoir thickness up to 250 $\mathrm{m}$ and porosity of $20-22 \%$ (Brown et al., 2001). The most likely source rock of the gas-condensate is the early Miocene to late Oligocene shale (Jenam Formation) in the basin centre and in the synclinal troughs between the fold trends. The source of oil has been presumed as the Late Oligocene shales. In both cases, the source rocks are terrestrial in origin (Shamsuddin, 1997). The generated hydrocarbons must have migrated relatively long distance in the traps, as the shales interbedded with or adjacent to the reservoirs are both lean and immature for hydrocarbon generation (Murphy et al., 1988). Hydrocarbon traps are mainly folded anticlinal plays. Stratigraphic plays like channel bodies (barrier bars and chenier), mouth bars, etc. forms additional play (Momin et al., 1999). 


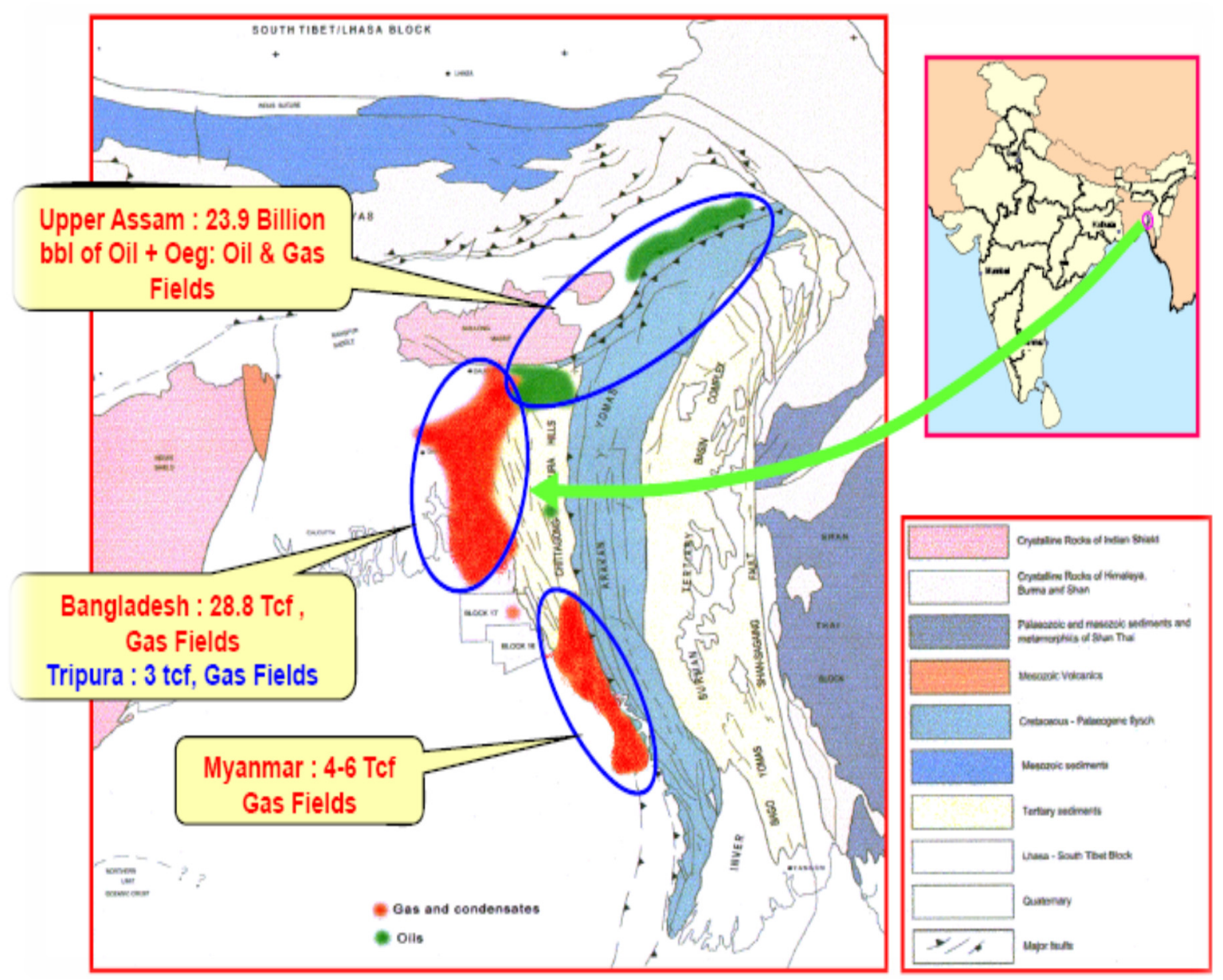

Figure 5. Oil and gas provinces in Assam-Arakan basin (DGH, 2011)

\subsection{Hydrocarbon Potential of Tripura}

Hydrocarbon exploration in Tripura started in 1962, drilling commenced in 1972 and gas was stuck in the first well drilled on the Baramura anticline in 1975 (Mane et al., 1999). From then, commercially viable multiple gas pools within Bokabil, Upper Bhuban and Middle Bhuban Formations have been discovered in Baramura, Gojalia, Rokhia and Agartala dome structures. These discoveries restricted to normal and upper transition pore pressure regime, have established the hydrocarbon potential of the shallow prospects of Tripura area (Figure 6). Hydrocarbon potential of deeper reservoirs within super pressure regime is not adequately established due to drilling complicacy related to over pressure. However, there are hydrocarbon indications reported in the super pressure sequence during drilling and testing with encouraging log response (Babu \& Sircar, 2011).

Carbon Isotope studies suggest that the gas reservoir in Tripura (methane content 95-97\%) is non-associated and thermogenic in origin, generated within the oil window at a late catagenic stage of maturation. Oligocene shales (Barail Formation) could also be a potential source (Uniyal et al., 1995). Besides, the Lower Bhuban strata penetrated in the deepest well in Rokhia have good source rating, capable of generating gas and condensate. Adjoining Cachar oil has been interpreted as a deeper palaeogene source (Pande et al., 1994b). Therefore, entrapment of both oil and gas in the deeper reservoirs within lower Bhuban and underlying Barail is a strong possibility. The argillaceous sequence of Bokabil and Bhubans of Surma Group act as suitable cap rocks.

Towards the north-eastern part of the study area, there are also occurrences of crude oil at shallow depths in the Cachar fold of Lower Assam in Badarpur, Hilara and Masimpur structures. Where, gas has been found in Adamtila, South Badarpur and Banaskandi structures. Reservoirs are located in the Bhuban and Barail formations and Miocene and Oligocene age respectively. 


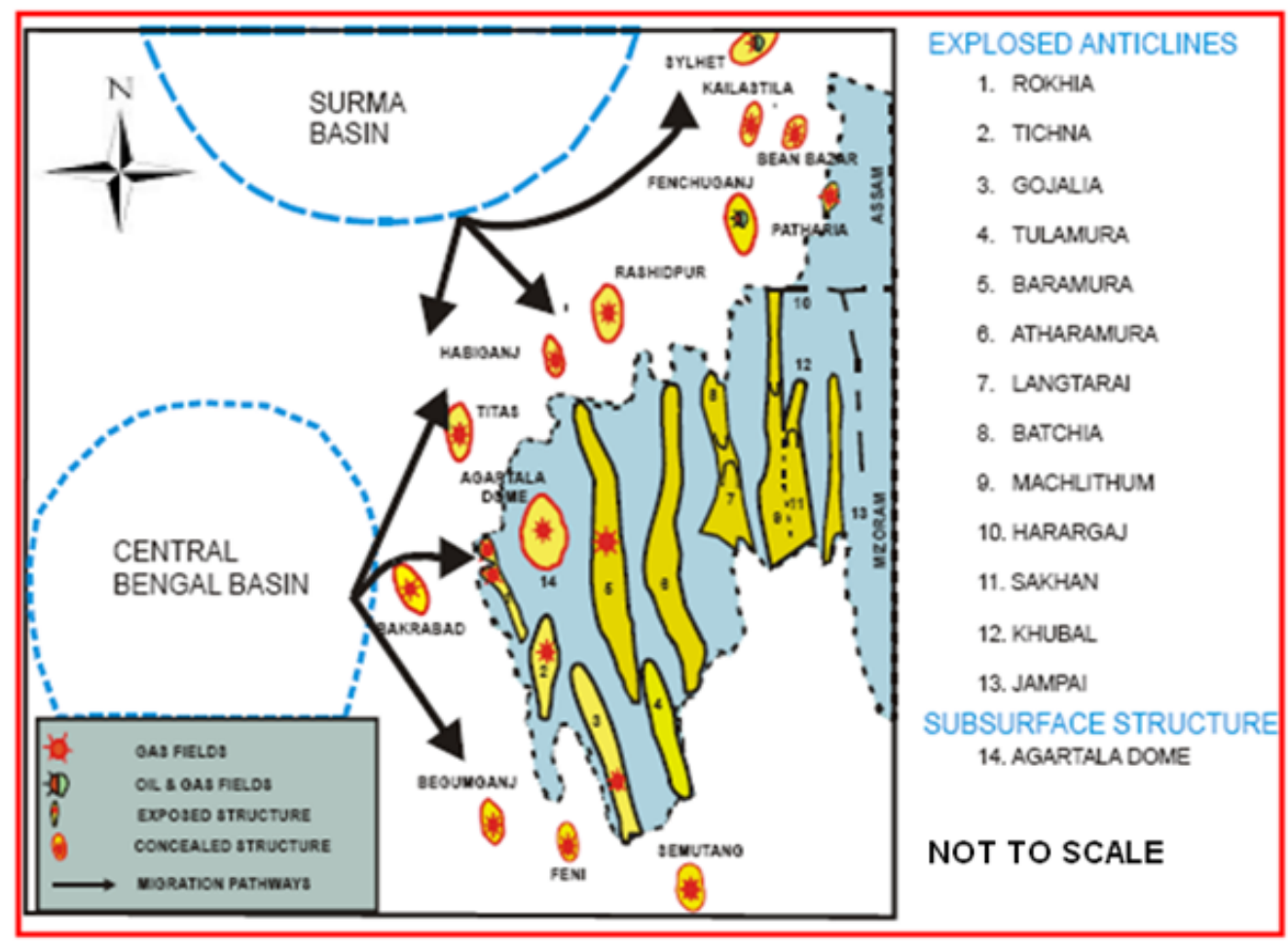

Figure 6. Hydrocarbon potential-Timing and migration (Jena et al., 2011)

The figure depicts the exposed structures and migration pathway from the depocentres namely Bengal and Surma sub-basins. Arrow is migration pathway shown in the Figure, dotted line is the outline of two sub - basins namely Bengal basin and Surma basin.

The carbon isotopic compositions are stable in Khoraghat - Nambar area of the Assam - Arakan Basin, India(Goswami et al., 2005). The oils in the Bokabil Formation (early to middle Miocene) can be correlated across the Khoraghat and Nambar field but the oil from Sylhet formation is different as compared to those in Bokabil formation. The potential source rocks in the Assam - Arakan basin are mainly late Eocene to early Oligocene Barail coal - shale and middle to late Eocene Kopili shale sequence. Kopili rocks have similar source specific parameters to those of the Sylhet oils, whereas genetically Barail rocks are correlatable with the Bokabil oils. There are two petroleum systems in Khoraghat - Nambar area namely, the Barail - Bokabil and the Kopili Sylhet (Goswami et al., 2005). The overlying Surma group sediments have relatively low organic contents with TOC values varying from $0.2 \%$ to $0.6 \%$ as compared to Barail group (Khan et al., 1988). In general Surma group has TOC below the threshold value $(0.5 \%)$ for a source bed (Tissot \& Welte, 1978; Waples, 1985) in Bangladesh side. The Surma group is not mature having average vitrinite reflectance $\left(\mathrm{R}_{0}\right)$ values ranges from $0.55 \%$ to 0.63\% (Shamsuddin \& Khan, 1999). The Eocene Kopili shales are potential sources of hydrocarbons in the Surma group (Leitz \& Kabir, 1982). Moreover in Surma group the sandstones show fairly good porosities (15\% $25 \%$ ) and permeabilities $(100-1500 \mathrm{mD})$, which are mostly sublitharenites, fine to medium grained, texturally mature with little clay and cements (Imam \& Shaw, 1985; Imam, 1987).

In the above discussion a broad similarity between the petroleum ingredients of Tripura and Bangladesh has been worked out. Although a common depocentre cannot be pointed out but the synclinal closures are capable in charging the potential hydrocarbon traps (Momin et al., 1999).

\section{Aerogravity Survey}

Aerogravity has helped to bring out the basement configuration (Figure 7). The northern part of the study lies on a gravity high, which goes down towards southeast in the northern part and towards south in the southern part. Gravity survey, conducted in Bengal and Assam-Arakan basins, covers the study area and its surrounding area. The Bouguer anomaly map shows that Tripura including the study area lies on regional gravity high trending NNE-SSW (DGH, 2008). 


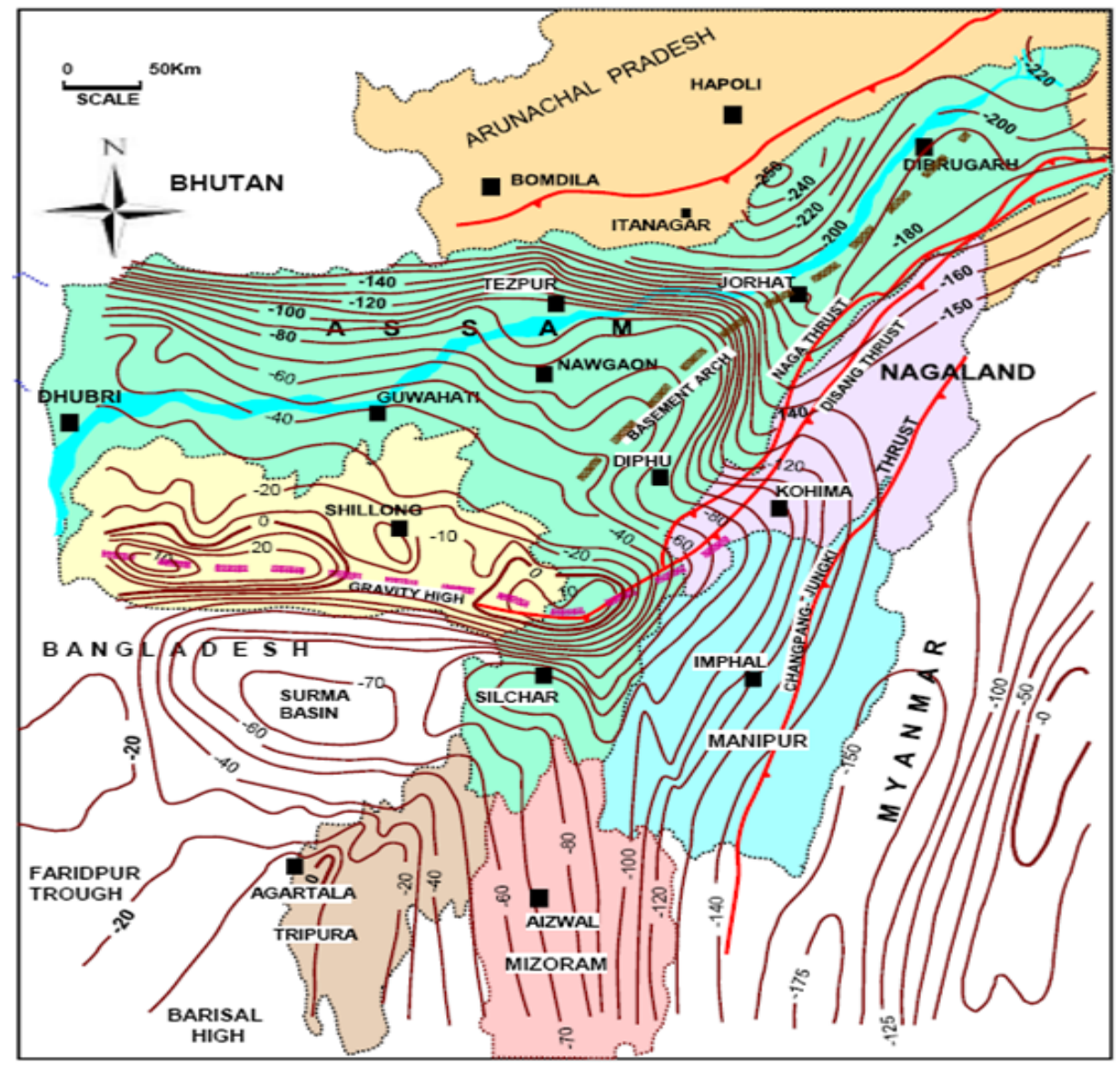

Figure 7. Aerogravity map (contour interval $10 \mathrm{mgal}$ barring $25 \mathrm{mgal}$ in the east) in and around the study area (DGH, 2011)

\section{Landsat Imagery Study}

The author analyzed the landsat imagery maps and geo-morphological interpretation were carried out. Structural and denudation processes dominate geomorphology of the Central Tripura. The Khowai syncline represents a structural valley with mounds of Dupitila. Overall drainage pattern in the north-western part of the area is dendritic and parallel to sub-parallel pattern in the southern part of Khowai and Dolai syncline. The most significant feature of the map is the presence of two dominant "geomorphic highs", one in the northern part of the area (annular) and the other on the northwestern part of the area (radial). It may be highlighted that Baramura gas field of ONGC forms part of the radial geomorphic high identified in the northern part of the area. These two anomalies are indicative of presence of sub-surface geological structure, which is important from hydrocarbon exploration point of view (Figure 8). The distinction between Upper and Lower Bhuban is also supported by trace fossil assemblage. The upper Bhuban is arenaceous predominating with sandstone, shale and siltstone separated by conformable and transitional contact from Middle Bhuban which is argillaceous. The Middle Bhuban is separated from Lower Bhuban (arenaceous in nature) by conformable and transitional contact (Raghabendra et al., 2011). 


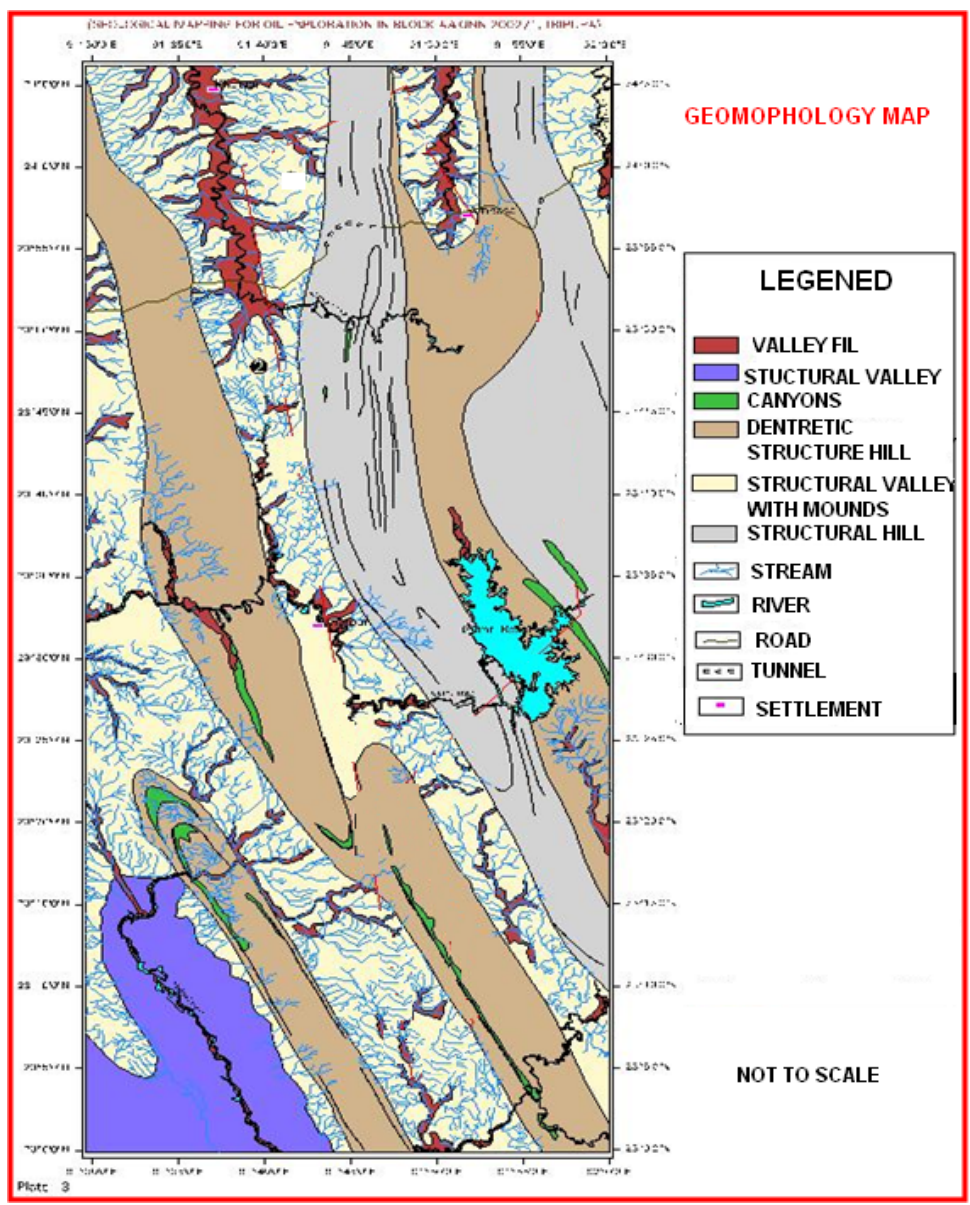

Figure 8. Geomorphological exposure in and around the study area

\section{Geological Mapping}

Geological field mapping have been carried out by Oil and Natural Gas Corporation of India Limited (ONGCL) in the study area covering the Atharamura and Tulamura anticlines that has helped to understand its structure and lithological character. It has been reported that about $50 \%$ of the total wells were drilled on the basis of surface geological mapping of which nearly $75 \%$ were successful and discovered as gas wells.

In the Tripura Fold Belt, the westward accurate folds have a general north-south trend and are generally disposed in enechelon pattern. The folds are becoming structurally higher eastward that is older and older units are exposed in the core of the anticlines. The eastern limbs of the anticlines are generally steeper and longitudinally faulted. A number of cross faults and lineaments are mapped from the satellite images. The terrain displays first order geomorphic features.

The Baramura anticline to the west is separated from the Atharamura anticline by the broad Khowai syncline, whereas to the east, the Batchia anticline is separated from Atharamura-Tulamura line of anticlines by the Dolai syncline. The N-S trending Atharamura anticline is the longest (about $100 \mathrm{~km}$ ) and largest of all the anticlines exposed in Tripura fold belt. It extends into Bangladesh in the south by more than $25 \mathrm{~km}$ and in the north, by about $2 \mathrm{~km}$. It has two culminations, the northern one being larger than the southern one. It covers an area of approximately 780 sq. km within the Central Tripura. The eastern limb of the anticline is steeper and shorter than the western one and is affected by a major longitudinal reverse fault, heading towards west. As per LANDSAT imagery data, the fold is also affected by two sets of cross faults; one set is oriented in NE-SW direction and the other, in NW - SE direction.

The NNW-SSE trending Tulamura anticline lies southwest of the Atharamura anticline. To the west, it is separated from Gojalia anticline by the Bopagha Syncline (Khar et al., 1984). The Tulamura anticline is disposed enechelon to the Baramura anticline towards south. The eastern limb of the Tulamura anticline is steeper and shorter than the western one and similar to the Atharamura anticline, and is traversed by a major longitudinal reverse fault heading towards west. Remote sensing maps shows the structure to be cut by a few cross faults. 
The Bokabil Formation is dominantly argillaceous in the study area. It contains a large number of sandstone beds and the Tipam sandstone Formation contains many shale beds. The Lower Tipam unit, shale-sandstone alteration and the Upper Tipam, dominantly sandstone with subordinate shales. The Bhuban and Bokabil formations are mainly dominated by mud or sand filled channels and incised valleys (Lee et al., 2001). Due to head ward erosion of submarine canyons or low stand sub aerial incision of valleys by channel networks these mud or sand filled channels are formed (Eliet et al., 1999). When those channels are filled by sand they form excellent stratigraphic traps, however they formed seals when filled with shale.

\section{Depositional Patterns}

Isopach maps (based on well data) of Upper Bhuban Formation (Figure 9a), and Surma Sequence (Thematic) (Figure 9c) are prepared as well as sand /shale ratio of Upper Bhuban Formation (Figure 9b), sand percentage of Bokabil Formation (Figure 9d) and sand percentage of Upper Bhuban Formation (Figure 9e) are also prepared for Tripura - Cachar area for better understanding of depositional patterns of the study area. Sand thickness derived from field traverses and drilled well suggests the following depositional pattern for the sediments: Upper Bhuban Formation, Surma Sequence (Thematic) and Bokabil Formations. The deposition of Upper Bhuban Formation in the northeast is only $600-700 \mathrm{~m}$ around Khowai, and Kamalpur due to limited subsidence in this area. The exposed Indian shield is located near the thickness of Upper Bhuban Formation in the Mizoram part $(800-900 \mathrm{~m})$ in the east and Rokhia part $(800-900 \mathrm{~m})$ towards the west. This shows an increase in thickness as this part is affected by tectonic loading, both from the east (Indo - Burma ranges) and the northeast (eastern Himalayas) which caused it to subside further, helping to accommodate huge thickness (4000-4500 m) of Miocene sediments of the Surma Sequence (Figure 9c). The sand/shale ratio has been estimated from various field traverses and drilled well data. The highest sand/shale ratio for the Upper Bhuban Formation (2.20) is at the Khowai and Kamalpur area in the northeast, gradually decreasing towards the south and Mizoram areas. In Eastern Tripura, the ratio is higher in Nutanbazar which decreases to 0.80 in Agartala; further west in Rokhia it is again 1.20 clearly indicating different sand lobes. The highest sand percentage for Upper Bhuban Formation $(68 \%)$ is at the Kamalpur area in the north-east, gradually decreases towards the Mizoram areas. In Eastern Tripura, the sand percentage is higher in Nutanbazar which decreases to $(50 \%)$ in Agartala; further west in Rokhia it is again 56\% clearly indicating different sand lobes. Therefore, from the sand/shale ratio map and sand percentage map of Upper Bhuban Formation, we have observed that there are two different sand lobes in Tripura.

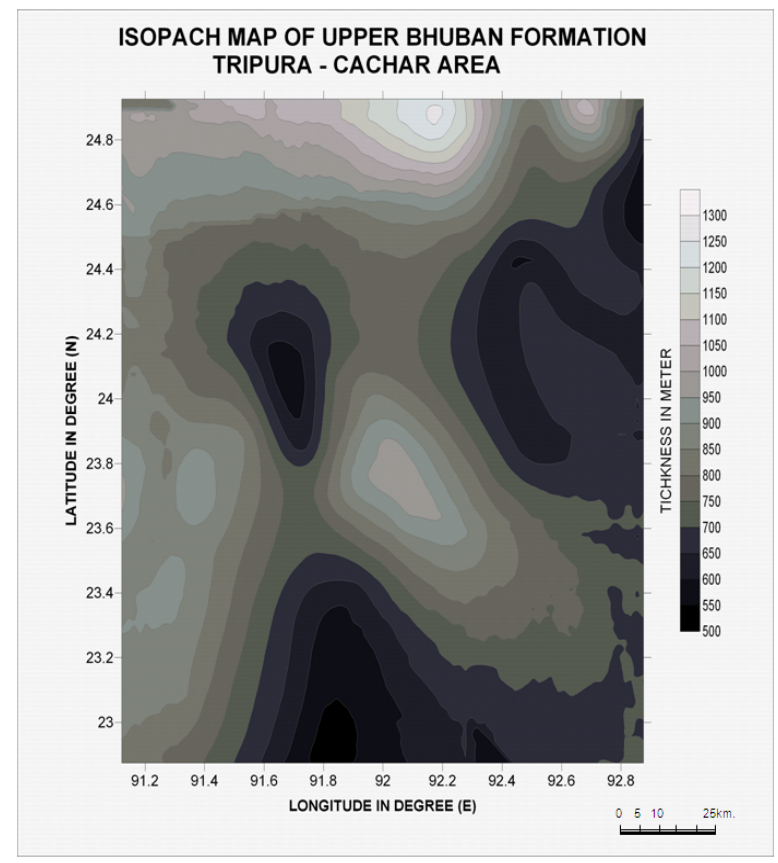

Figure 9a. Isopach map (based on well data) of Upper Bhuban formation in Tripura - Cachar area (Western boundary of Assam with Tripura)

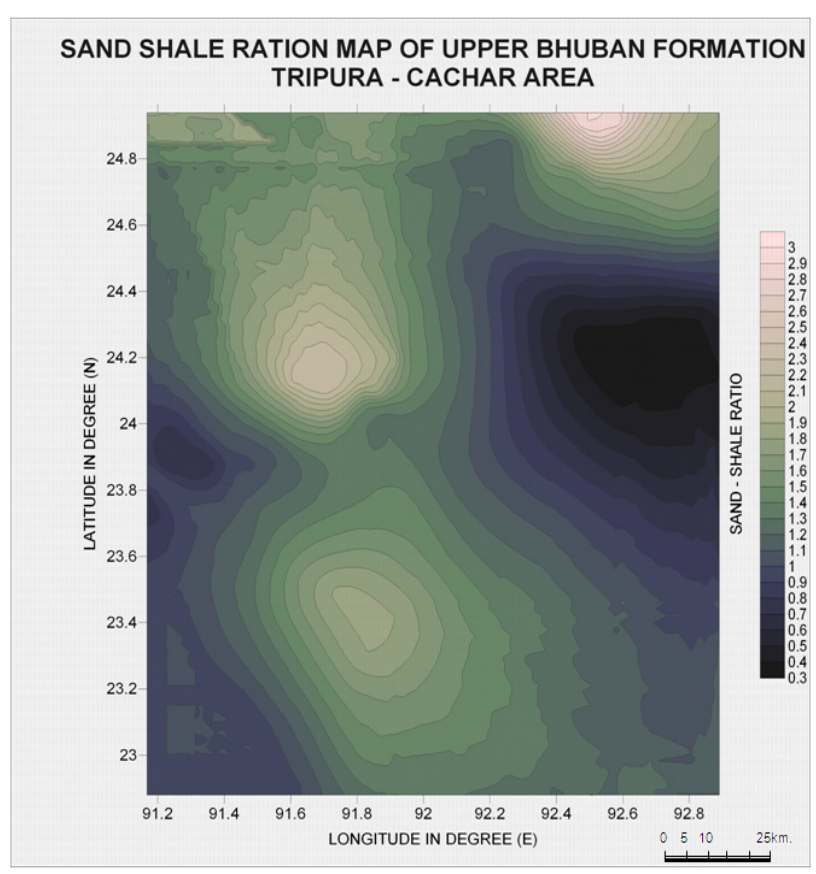

Figure 9b. Sand Shale ratio map (based on well data) of upper Bhuban formation in Tripura - Cachar area

(Western boundary of Assam with Tripura) 


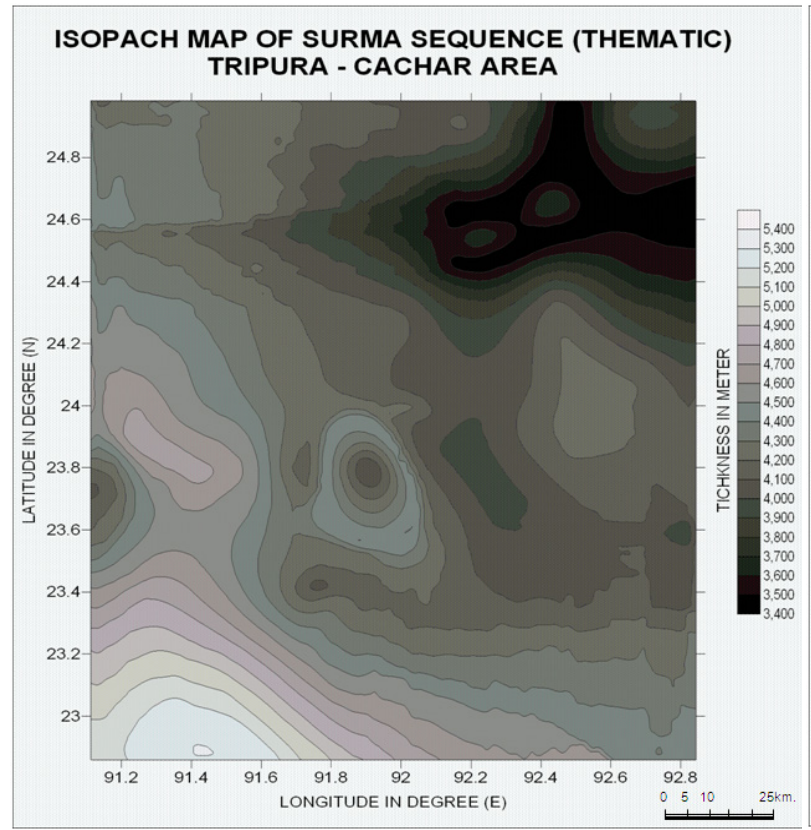

Figure 9c. Isopach map (based on well data) of Surma Sequence (Thematic) in Tripura - Cachar area (Western boundary of Assam with Tripura)

\section{SAND PERCENTAGE MAP OF BOKABIL FORMATION} TRIPURA - CACHAR AREA

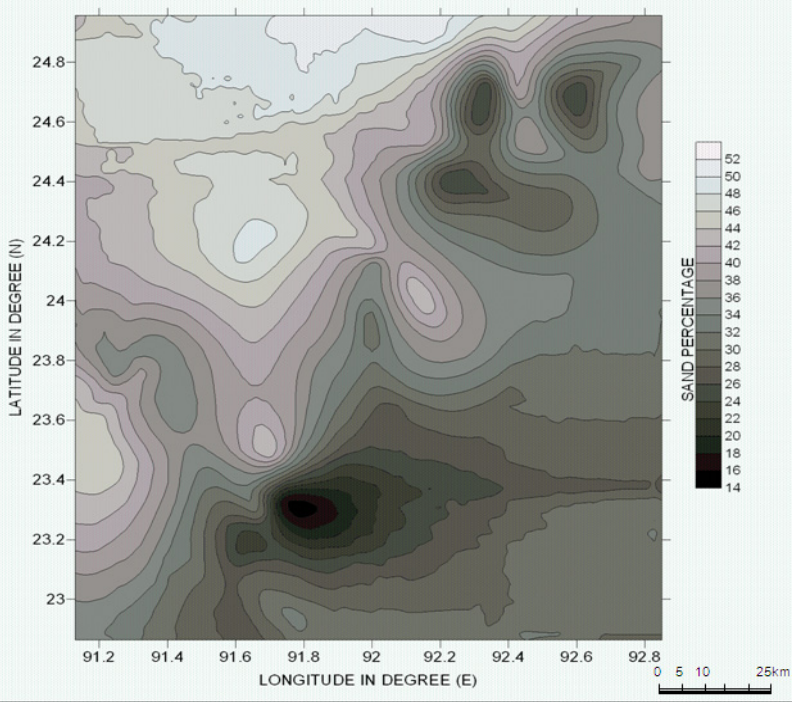

Figure 9d. Sand percentage map (based on well data) of Bokabil formation in Tripura - Cachar area (Western boundary of Assam with Tripura)

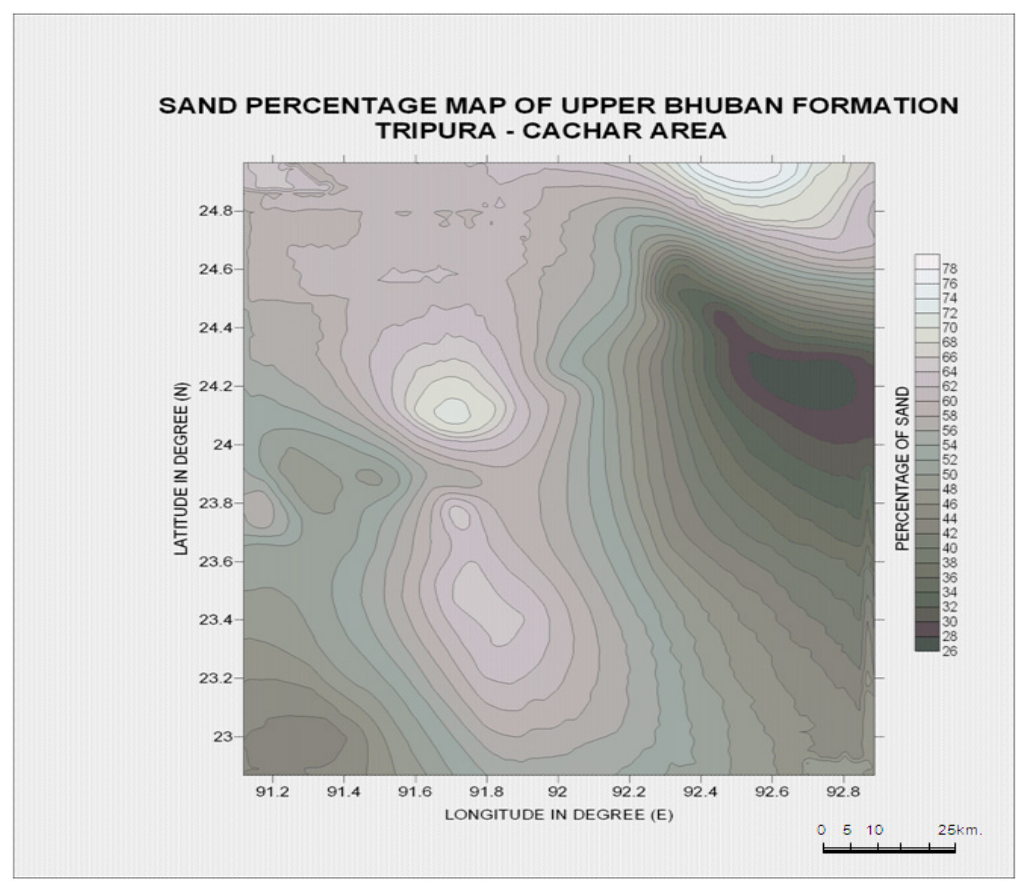

Figure 9e. Sand percentage map (based on well data) of Upper Bhuban formation in Tripura - Cachar area (Western boundary of Assam with Tripura)

\section{Geochemical Analysis}

Numerous surface and subsurface manifestations of natural gas in Tripura suggests the existence of conditions conducive to hydrocarbon generation in this region (Ganguly, 1983). The geochemical studies carried out in the area (Figure 10) indicate that the surface hydrocarbon regime has not been generally perturbed by the upward migration of subsurface hydrocarbon accumulation (Khan et al., 1999). However, considering methane anomalies and propane as one of the established hydrocarbon proximity indicator, one may look for prioritizing 
geomorphologically or seismically mapped prospects in the region between Teliamura-Ambassa where central part of the area shows gas ooze with high methane and propane concentrations around Kaiphang (southern tail of the area). The analysis shows that $97 \%$ of the samples are characterized by varying concentration of methane from 1- $79 \mathrm{ppb}$ and few samples have ethane, propane, isobutane and normal butane. These numerous surface and subsurface manifestation of natural gas in Tripura suggest existence of conditions conducive to petroleum generation in the region.

\section{Seismic Studies}

Within the study area, Common Depth Points (CDP) seismic surveys were conducted acquiring 24 fold data in limited areas of the Khowai and Dolai synclines by various Indian oil companies. These lines acquired along the roads and nallas are crooked in nature. Interpretation of seismic data from the area is beset with difficulties such as (a) statics, (b) tie between various campaigns: seismic lines belong to different vintages, each set of lines having widely separated ground locations with no connectivity in between, (c) multiples in the lower levels, and (d) poor imaging of deeper levels.

Seismic data interpretation helps to identify low relief reversals of the area, but has limitations while imaging the core of anticlines. As a result, gently dipping area towards the plunge of anticlines give relatively better quality of seismic data than the highly dipping crested area.

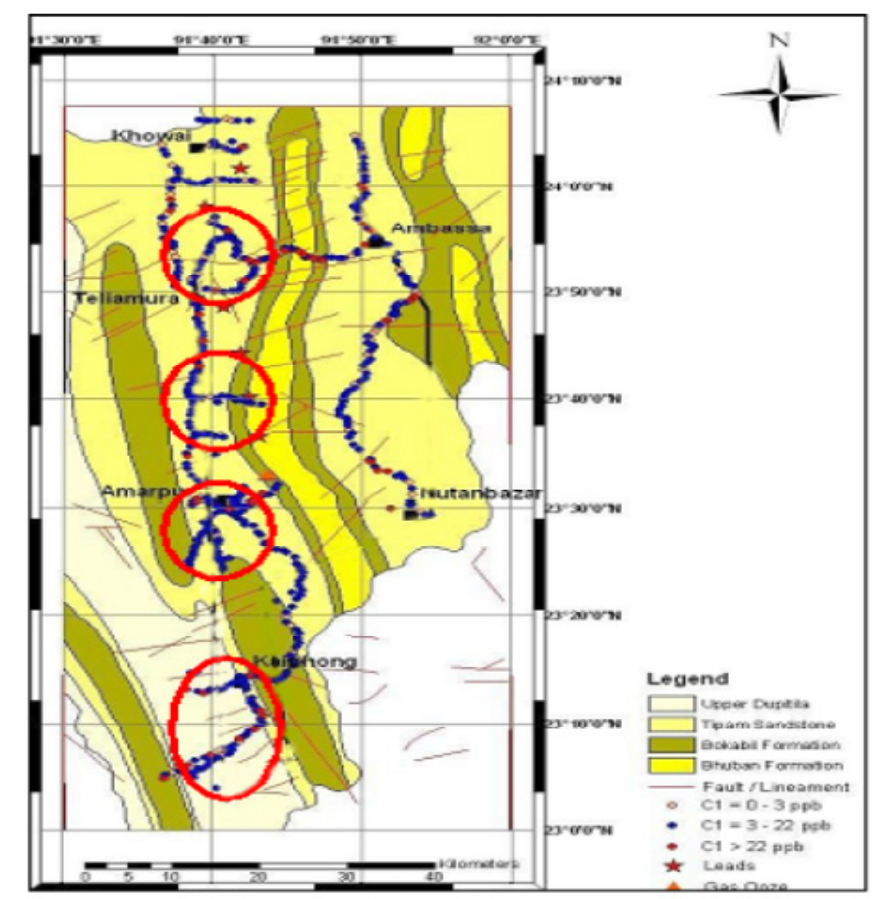

Figure 10. Geochemical survey map showing the concentration of Methane, Ethane, Propane etc. The red circle indicates the zones where hydrocarbon is oozing out to surface (Source: NGRI Research Team, 2008)

\subsection{Seismic Reprocessing and Interpretation}

Reprocessing efforts made by Polish companies have significantly improved these seismic studies in terms of continuity of reflectors and strength, whereby it has become possible to pick up reflector up to the level of 3000 ms. Various structural features like faults, anticlinal trends are also more confidently mapped in the reprocessed data compared to the originally processed data (Figure 11). Pre-stack time and depth migration have been applied to the data with various levels of iterative residual statics.

Available 2D seismics have given the idea of structure of only the synclinal parts of the area (Richards et al., 2003). Interpretation of 2D seismics show some reversals in N-S orienting lines, however, it was not possible to map the areal extension of all these structural reversals due to absence of adequate cross lines. The most convincing structure is found near the Teliamura, which is a three-way dip closure. Further evidences were provided by remote sensing maps, showing the surface impression of a possible subsurface high, i.e., a 
geomorphic high, characterized by the annular drainage pattern. This kind of concealed low amplitude subsurface structural highs indicated by the photogeological and Landsat image analysis within the synclinal areas can be prospective (Momin et al., 1999). Agartala Dome gas field is one such concealed structure located within Agartala syncline (Figure 6).

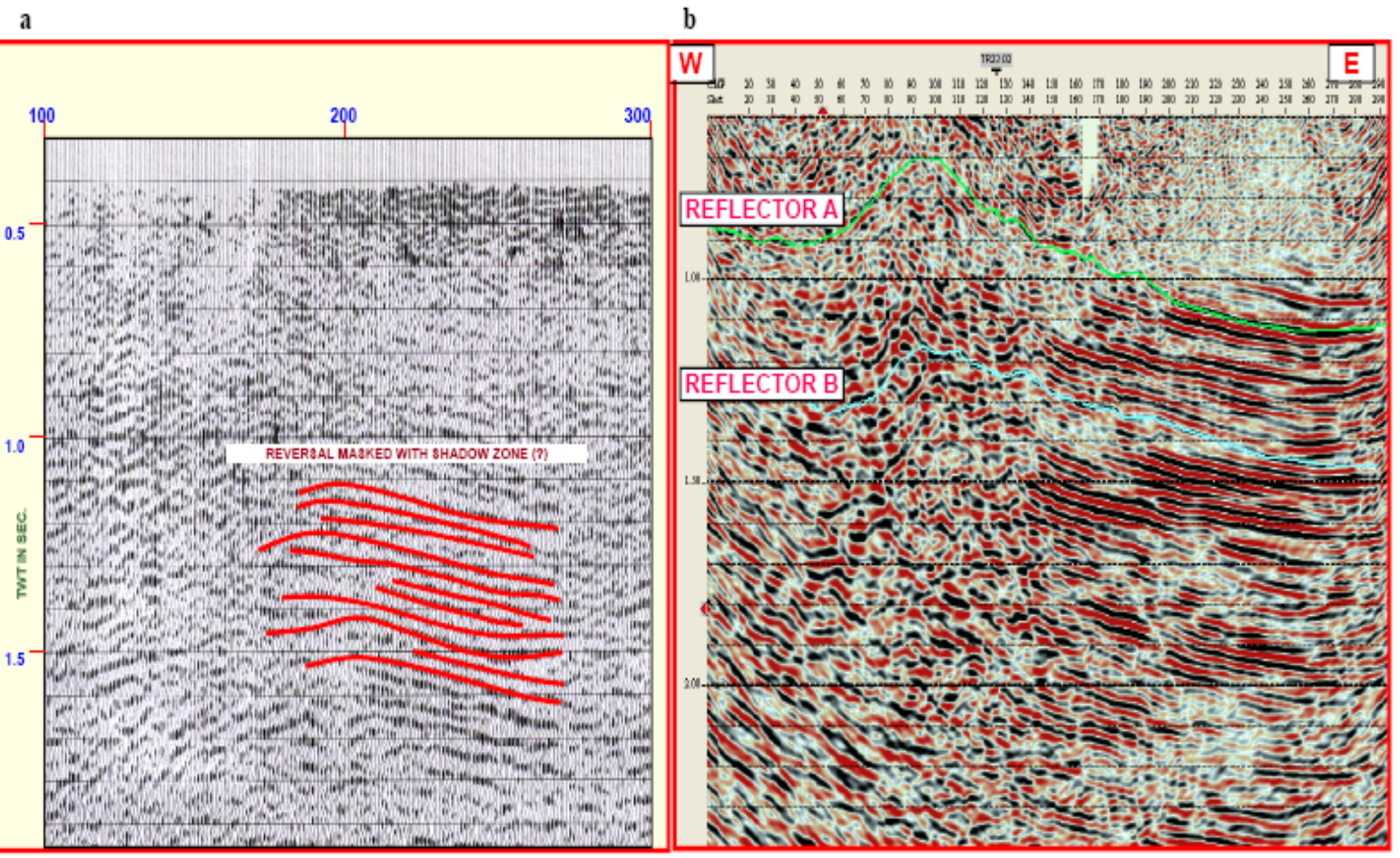

Figure 11. Typical seismic line depicting reversal with masked shadow zone (a) Reversal masked with shadow zone

The anticlinal trend on the crest is chaotic (before reprocessing), (b) Reprocessing helped to overcome shadow zone to a great extent and highlighted reflector continuity over crestal part of reversal with plausible interpretation of continuous reflectors. (Refer Seismic Line-1 in Figure 1)

Few parallel seismic lines in the western flank of Tulamura anticline have depicted wipe out zone (gas shadow zone). Immediately north of this feature, gas has been collected during a recent field survey. Figure 13 shows high amplitude reflectors in patches are observed in reprocessed seismic sections, which are difficult to correlate across faults and the area being located in structurally complex area, such section requires structural balancing, in order to understand the paleostructure of the area and to compute a geological model (Refer to Seismic Line-1 in Figure 2). The interpretation of geo-seismic sections is considered to be greatly assisted by careful application of geometrical balance and a consideration of strain even in areas of low crustal extensions. The shot gathers of seismic CDP have been analyzed on all the parallel lines. The weak reflector zone identified has not attributed to mechanical failure during seismic shooting.

\section{Hydrocarbon Plays in the Study Area}

Based on hydrocarbon occurrences and established formation pressure regime of Tripura and adjoining Bangladesh, the exploration target of the study area can be divided into two parts: Shallow prospect exploration within normal and upper transition pressure regime and Deeper prospect exploration in abnormally high-pressure regime and underlying Barails (Momin et al., 1999)

\subsection{Shallow Exploration Targets}

It includes mainly the shallow reservoirs, which are primarily controlled by structure along with stratigraphic variations like channel cut and fills, lensoidal sand bodies as additional plays. The potential source is established as deep, from where hydrocarbons are migrated and entrapped in these shallow stratigraphic comes structural plays. This phenomenon and the in situ generation of gas-condensate from Lower Bhuban shales make the 
exploration of synclinal areas attractive as tectonic influence is minimal and preserve better cooking environment for longer time as compared to the anticlines which were shadowed up. Therefore, the concealed low amplitude structural highs indicated by the photogeological and Landsat image analysis within the synclinal areas merit attention. Agartala Dome gas field is one such concealed structure located within Agartala syncline (Momin et al., 1999).

However, there is a risk of escaping of gas in the areas of structural complexities (from east of Atharamura). This could be a very convincible explanation of why the wells at Harargaj went dry in spite of continuous gas shows observed during drilling. Hence, exploratory success for shallow prospects lies in the comparatively less disturbed plunge areas of these complex structures where the younger rocks form the potential cap and the deep-seated younger cross faults provide the trapping mechanisms (Momin et al., 1999). The gentle plunge of the Tulamura anticline has such a high possibility of being hydrocarbon bearing like the Gojalia structure which is in the immediate west of this anticline.

\subsection{Deeper Exploration Targets}

Scanty well data and poor seismic response below the Middle Bhuban are the prime constraints for a fruitful resource assessment for the deeper prospects. Surface geological mapping envisages a comparatively flatter and gentler closure of pre-Bhuban sequences, which is supported by offset VSP data over Khubal anticline in eastern Tripura. It also indicated the occurrence of Barail at a depth of around $3960 \mathrm{~m}$ (abs.), in Khubal. VSP-PIVT trends in a number of wells predict possible pressure regression below Lower Bhuban (Singh et al., 1997). The role of overpressure sequence below the middle part of the Middle Bhuban has a great significance in hydrocarbon migration. This overpressure seal might have formed a partial barrier to the upward movement of hydrocarbon and thus, favored accumulation within the reservoir facies of overpressure sequence and underlying Oligocene reservoirs of Barail Formation. (Momin et al., 1999). More than $3000 \mathrm{~m}$ thickness of the Eocene and Oligocene Barail group rocks is deposited on the top of the Kopili. The Barail lower are arenaceous unit and the upper Barail coal - shale unit are the two divisions of the Barail group. Mainly, Main Pay sand, the main lower sand and minor shales with a combined thickness of as much as $900 \mathrm{~m}$ are deposited in Barail lower arenaceous unit. However the upper Barail group coal - shale unit consists of as much as $1200 \mathrm{~m}$ of inter-beded coals, shales and discontinuous sandstones reservoirs deposited in a delta - plain environment. In between Naga and Disang thrusts the thicknesses of upper Eocene and Oligocene Barail coal - shale unit reaches a maximum $660 \mathrm{~m}$ (Balan et al., 1997). Barail coal - shale unit has Total Organic Content (TOC) values ranging from less than $0.8 \%$ to more than $12 \%$. In the Assam geological province Barail formation is considered as primary source rock. However the Miocene Surma group Bhuban formation if hypothesized to be the most likely source rocks (Balan et al., 1997).

In Tripura area, gas entrapment is mostly controlled by structures (Figure 12). Here, we discuss possible hydrocarbon plays in the study area, analogy drawn from neighboring various discoveries:

i. The presence of first order topography in Tripura wherein the structures manifested on the surface continue in the subsurface with minor changes is a criterion noticeable at the first sight from the structural point of view with a shift in the axis as we propagate downwards.

ii. In this province, ENE - WSW strike slip faults control entrapment along anticline axis. Separate closures within the same anticline have different pools. Sinuosity of Atharamura structure, possibly the effect of younger cross cutting strike slip faults resulting into the displacement of axis and compartmentalizing the structure into three main parts, the structurally highest portion, the central compartment and lower fragmented portion plunging into Bangladesh. If it is compared to the nearby Baramura structure, these cross cutting faults plays vital role in defining the prospectivity of this structure, because the Baramura gas field is defined by an N-S orienting reverse fault in its eastern limb and ENE-WSW crosscutting faults thereby limiting the structure in its northern culmination.

iii. Crest and plunge of anticlines: Crest and plunge along the axis of anticlines of Tripura Cachar Fold Belt have already been proved as highly prospective by the various gas discoveries. The Tulamura anticline is enechelon to the gas bearing Baramura anticline. Towards the immediate east of Tulamura is the Gojalia anticline, which is having a similar structural set up like Tulamura. This Gojalia anticline is enechelon to Rokhia and Tichna anticline respectively in the west and northwest. The plunge of this Gojalia anticline has proved hydrocarbon entrapment. Similarly, at the plunge of the Atharamura anticline, Moulavi Bazar gas field is located (in Bangladesh). As such, the plunge of the Tulamura anticline, which is within the study area, merits attention. Although a number of crosscutting faults have divided the Atharamura anticline into a number of compartments, the flank part of the anticline is less 
affected. This means that these parts of the anticline are less compartmentalized. As there is no report of gas seeps up dip it provides a possibility of encountering leads in the flank parts, which are sealed by conceptualized faults. The sealing faults could be against sandstone-mudstone contact or by smearing clay down the fault plane along sandstone- sandstone contacts.

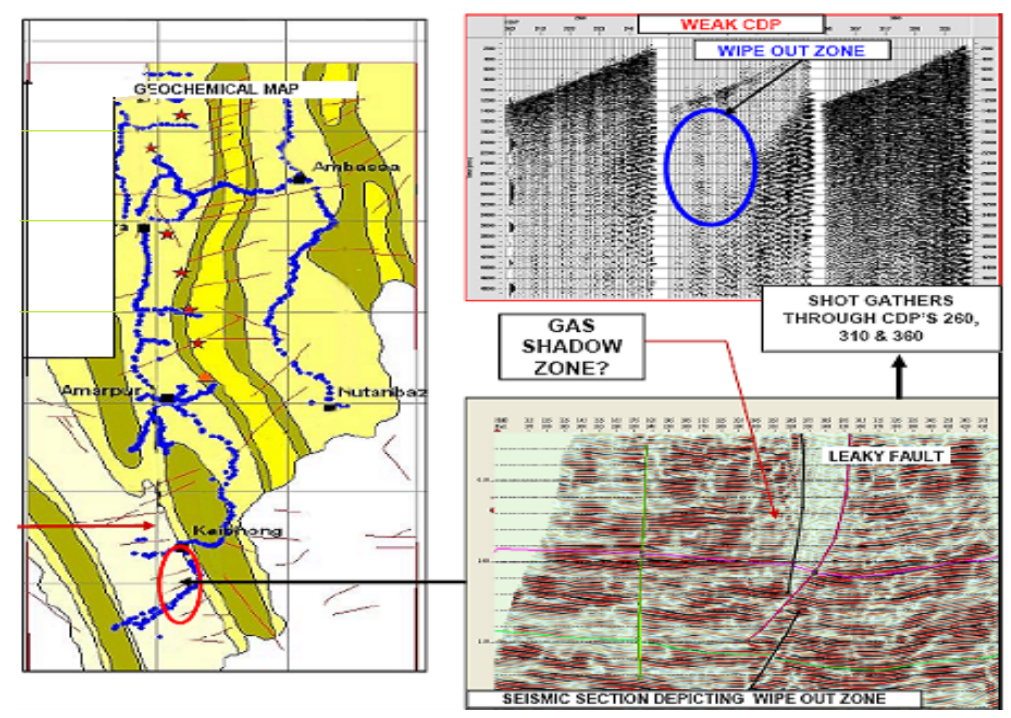

Figure 12. Gas seepage near the study area

The same is also seen in the shot gather and in the SEGY seismic data. The leaky faults were identified which are the conduits which oozes out hydrocarbon to the surface. This is also confirmed by geochemical anomalies.

\section{Risking of Plays}

Central Tripura is riddled with risk. The structural deposition of anticlines and synclines possess largest challenge from exploration point of view. Some of the risk indentified is described as followings:

i. The study area is highly dominated by faults and thrusts and presents two kinds of risks of prospects. Nature of the faults (whether sealed or leaky) plays a vital role in defining the chances of hydrocarbons trapped in structural plays. Gas seepages are quite common in this area, where faults are mainly acting as conduits for gas to escape. Apart from these, faults, whether medium angled or low angle reverse fault (thrust) is also important in defining the reservoir geometry and extent.

ii. Plunge angle of the anticlines, steep or gentle, plays another important role in the risking of various structural plays. Gentle plunge of anticlines less deformed by tectonic activities are considered as more prospective.

iii. Taking into consideration of the failure of an Indian company in drilling well $\mathrm{X}$ which was drilled in a concealed structure (seen as geomorphic high) within the syncline in the close proximity of the study area brings into light another risk in terms of charging of these kind of subtle structures. However, Agartala Dome is a well-established hydrocarbon bearing structure.

iv. Structures having steeper dips of $>50^{\circ}$ have severe challenges in drilling like Hararganj-1 well. Most discoveries are known from formations having less than $30^{\circ}$ dips.

v. Formation pressure is another very important aspect, especially for deeper targets. $90 \%$ reservoirs are known within hydrostatic pressure regime; $10 \%$ within transition pressure regime; none in super pressure regime. High pressure and high temperature of the formation is a major constraint in completing many wells in both Tripura and Bangladesh area. 

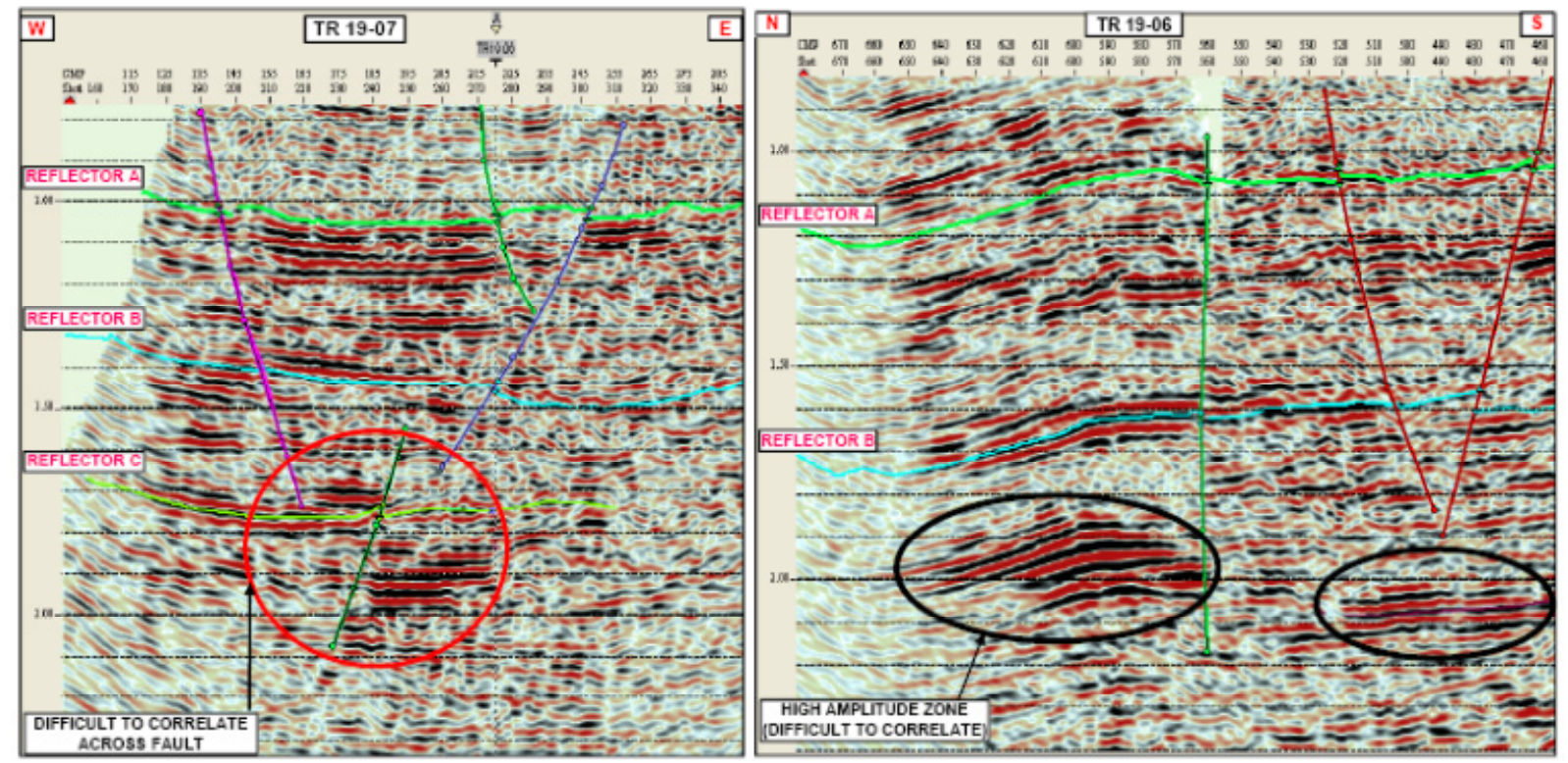

Figure 13. Structural balancing (High amplitude reflectors in patches are observed in reprocessed seismic sections, which are difficult to correlate across faults and the area being located in structurally complex area

\section{Discussion and Conclusions}

i. Till recent time geological mapping was widely used in finding out various structural plays in this region. The available seismic data are affected by structural complexity of the region, such as shadowing effect of steeply dipping structures. The scanty seismic data are not adequate enough in proper imaging the deeper level. In order to minimize the above-mentioned limitations and constraints, the new seismic may be acquired to achieve better reflector continuing by applying ground mixing.

ii. The prospects in the syncline are mainly concealed anticline within syncline. The anticlines in the study area are less explored and more exploration activities need to be carried out to exploit the potential of the same.

iii. The risk envisaged has been listed down and hydrocarbon prospectivity evaluated mostly in terms of geological and geophysical signatures.

iv. The study made an integrated approach to understand the geological and geophysical constraint in exploration activity in the area and the authors have tried to provide solution in overcoming the same.

\section{Acknowledgement}

The authors would like to thank the appropriate authorities who have helped them to publish this paper in this journal.

\section{References}

Akram, S. M., Mudiar, B., \& Sahu, A. (2004). Geodata integration leads to reserve accreation in Baramura gas field of Tripura, Assam-Arakan Fold Belt - A case study. $5^{\text {th }}$ Conference and Exposition on Petroleum Geophysics, Hyderabad, India, 767-771.

Alam, M. (1989). Geology and depositional history of Cenozoic sediments of the Bengal Basin of Bangladesh, Palaeogeography, Palaeoclimatology, Palaeoecology. Palaeogeography, Palaeoclimatology, Palaeoecology, 69, 125-139. http://dx.doi.org/10.1016/0031-0182(89)90159-4

Babu, S., \& Sircar, A. (2011). A comparative study of predicted and actual pore pressures in Tripura, India. Journal of Petroleum Technology and Alternative Fuels, 2(9), 150-160.

Balan, K. C., Banerjee, B., Pati, L. N., Shilpkar, K. B., Pandey, M. N., Sinha, M. K., \& Zutshi, P. I. (1997). Quantitative genetic modeling of Upper Assam Shelf. Proceedings $2^{\text {nd }}$ International Petroleum Conference \& Exhibition, Petrotech, New Delhi, India, 1, 341-349.

Brown, T. A., Shamsuddin, A. H. M., \& Rickard, M. J. (2001). Hydrocarbon resource base of Bangladesh. Proceedings of the $13^{\text {th }}$ Offshore South Asia (SEAPEX) Conference, 79-84. 
Chakravorty, D., Gupta S., Shyam, R., \& Bandari A. (2011). A Re - look into exploration strategy of Lower Bhuban play in Eastern Tripura, India - A case study. The $2^{\text {nd }}$ South Asain Geoscience Conference and Exhibition, GEOIndia 2011, Greater Noida, New Delhi, India.

Curiale, J. A., Covington, G. H., Shamsuddin, A. H. M., Morelos, J. A., \& Shamsuddin, A. K. M. (2002). Origin of petroleum in Bangladesh. AAPG Bulletin, 86, 625-652.

Dasgupta, P. K., Chakraborty, P. K., \& Dutta, D. (1991). Basinward migrating submarine fan environment from Barail group in North Cachar Hills, Assam Arakan Orogen, India. In A. H. Bouma, \& R. M. Carter (Eds.), Facies Models in Exploration and Development of Hydrocarbon and OreDeposits: VSP, Utrecht, the Netherlands (p. 254).

Eliet, P., Edward, A. F., Mingard, H. F., \& Talukder, Y. A. (1999). Fore-stepping progradational to aggradational sequence stacking geometries, offshore Bangladesh: Implication for reservoir development. Proceedings of $2^{\text {nd }}$ Petroleum Engineering Symposium, Bangladesh University of Engineering and Technology, Dhaka, 19.

Ganguly, S. (1983). Geology and Hydrocarbon prospects of Tertiary succession of Tripura-Cachar-Mizoram region. Petroleum Asia journal, 1, 105-109.

Ganguly, S. (1993). Stratigraphy, Sedimentation and Hydrocarbon prospects of the tertiary succession of Tripura and Cachar (Assam). Indian Journal of Geology, 65, 145-108.

Gani, M. R., \& Alam, M. M. (1999). Trench-slope controlled deep-sea clastics in the exposed lower Surma Group in south - eastern Fold Belt of the Bengal Basin, Bangladesh. Sedimentary Geology, 127, 221-236. http://dx.doi.org/10.1016/S0037-0738(99)00050-0

Goswami, B. G., Bisht, R. S., Bhatnagar, A. K., Kumar, D., Pangtey, K. L., Mittal, A. K., Geol, J. P., Datta, G. C., \& Thomas, N. J. (2005). Geochemical characterization and source investigation of oils discovered in Khoraghat - Nambar structures of the Assam - Arakan Basin, India. Organic Geochemistry, 36, 161-181. http://dx.doi.org/10.1016/j.orggeochem.2004.08.002

Holtrop, J. F., \& Keizer, J. (1970). Some aspects of stratigraphy and correlation of the Surma Basin wells, East Pakistan. ESCAFE Mineral Resources Development Series, 36, 143-154.

Hossain, H. M. Z., Sampei, Y., \& Roser, B. P. (2009). Characterization of organic matter and depositional environment of Tertiary mudstones from the Sylhet Basin, Bangladesh. Organic Geochemistry, 40, 743-754. http://dx.doi.org/10.1016/j.orggeochem.2009.04.009

Imam, B., \& Hussain, M. (2002). A review of hydrocarbon habitat in Bangladesh. Journal of Petroleum Geology, 25(1), 31-52. http://dx.doi.org/10.1111/j.1747-5457.2002.tb00098.x

Imam, M. B., \& Shaw, H. F. (1985). The diagenesis of Neogene clastic sediments from the Bengal Basin, Bangladesh. Journal Sed. Petrol., 55, 665-671.

Imam, M. B. (1987). Implications of shale diagenesis on cementation of reservoir sandstones in Neogene Surma Group, Bengal Basin, Bangladesh. Journal Geol. Soc. India, 30, 447-492.

Jena, A. K., Das, N. C., Saha, G. C., \& Asim, S. (2011). Exploration in Synclinal Area of Tripura Fold Belt, India: A re - found Opportunity. Expanded abstract presentation at AAPG Annual Convention and Exhibition, Houston, Texas, USA, April 10-13.

Johnson, S. Y., \& Nur Alam, A. M., (1991). Sedimentation and tectonics of the Sylhet trough, Bangladesh. Geological Society of America Bulletin, 103, 1513-1527. http://dx.doi.org/10.1130/0016-7606(1991)103<1513:SATOTS >2.3.CO;2

Khan, A. A., \& Imaduddin, M. (1999). Petroleum exploration and production in Bangladesh: prospect and problems. Proceedings of the $43^{\text {rd }}$ Convention of the Institute of Engineers, 27-32.

Khar, B. M., \& Ganju, J. L. (1984). Tectonic of Tripura folds - probable mechanics of folding and faulting. Petroleum Asian Journal, 1, 66-77.

Khan, M. A. M., Ismail, M., \& Ahmed, M. (1988). Geology and hydrocarbon prospect of the Surma Basin, Bangladesh. $7^{\text {th }}$ Offshore Southeast Asia Conf. Singapore, 364-387.

Khan, R. M. S., Geol, J. P., Sharma, A. K., Pande, A., Mathur, M., \& Misra, K. N. (1999). Geochemical model for the generation of condensates in Tripura area. Proceeding of the $3^{r d}$ Int. Pet. Conf. and Exbn. Petrotech, New Delhi, India, 207-212. 
Kunte, S. V. (1989). Tripura - Cachar fold belt genesis of structural style. ONGC Bulletin, 26(2), 1-15.

Lee, Y. F. S., Brown, T. A., Shamsuddin, A. H. M., \& Ahmed, N. U. (2001). Stratigraphic complexity of the Bhuban and Bokabil formations, Surma Basin, Bangladesh: Implications for reservoir management and stratigraphic traps. $10^{\text {th }}$ Geological Conference, Bangladesh Geological Society, Dhaka, 25.

Leitz, J. K., \& Kabir, J. (1982). Prospects and constraints of oil exploration in Bangladesh. In Proc. $4^{\text {th }}$ Offshore Southeast Asia Conference, Singapore, 1-6.

Mane, P. H., Santanu, D., Bhattacharya, H. S., \& Monin, W. W. (1999). Petroleum System of Miocene Sediments of Western Tripura. Proceeding of the $3^{\text {rd }}$ Int. Pet. Conf. and Exbn. Petrotech, New Delhi, India, 69-72.

Momin, W. W., \& Choudhury, A. (1999). Evaluation of Tripura subbasin with special reference to the hydrocarbon province of Bangladesh gas fields. Proceeding of the $3^{\text {rd }}$ Int. Pet. Conf. and Exbn. Petrotech, New Delhi, India, 63-68.

Murphy, R. W. (1988). Bangladesh enters the oil era. Oil and Gas Journal, 86(9), 76-82.

Nanjundaswamy, S., \& Kandwal, A. K. (1993). Paleoenvironmental and Paleogeographic analysis of Tripura area. Proceeding of the $2^{\text {nd }}$ seminar on Petroliferous Basins of India, 1, 613-624.

Pande, A., Uniyal, A. K., \& Chandra, K. (1994). Genetic correlation of biodegraded crude oils from Lower Assam, India using biomarker composition. Organic Geochemistry, 21, 971-977. http://dx.doi.org/10.1016/0146-6380(94)90055-8

Richards, D. R., Calvert, S. J., \& Yamamoto, H. (2003). 2D And 3D Structural Balancing in a Deformed Foreland Basin, Peruvian Subandean Belt. ${ }^{\text {th }}$ Simposio Bolivarino, 141-145.

Shamsuddin, A. H. M., \& Khan, S. I. (1991). Geochemical criteria of migration of natural gases in the Miocene sediments of the Bengal Foredeep, Bangladesh. Journal of Southeast Asian Earth Sciences, 5, 9-100. http://dx.doi.org/10.1016/0743-9547(91)90016-Q

Shamsuddin, A. H. M., \& Abdullah, S. K. M. (1997). Geologic evolution of the Bengal basin and its implication in hydrocarbon exploration in Bangladesh. Indian Journal of Geology, 69, 93-121.

Singh, K., Chaudhury, A., \& Bhattacharyya, N. (1997). Application of VSP for drilling overpressure wells in Tripura. Journal of Geophysics, 18(1), 15-26.

Tiwari, R. P., Rajkonwar, C. L., Paul, L. J. M., Ralte, V. Z., \& Patel, S. J. (2011). Trace fossils from Bhuban Formation, Surma Group (Lower to Middle Miocene) of Mizoram India and their palaeoenvironmental significance. Journal of Earth System Science, 120(6), 1127-1143. http://dx.doi.org/10.1007/s12040-011-0131-0

Tissot, B. P., \& Welte, D. H. (1978). Petroleum Formation and Occurrence - A New approach to Oil and Gas Exploration (p. 538). Springer-Verlag, Berlin. http://dx.doi.org/10.1007/978-3-642-96446-6

Uddin, A., \& Lundberg, N. (1999). A parleo - Brahmaputra? Subsurface lithofacies analysis of Miocene deltaic sediments in Himalayan - Bengal, system, Bangladesh. Sedimentary Geology, 123, 239-254. http://dx.doi.org/10.1016/S0037-0738(98)00134-1

Uniyal, A. K., Mittal, A. K., Dwivedi, P., Chandra, U., Benerji, V., Dhawan, R., \& Mathur, M. (1995). Genetic classification of Natural Gases of Tripura - Cachar, India. Proceeding of the $1^{\text {st }}$ Int. Pet. Conf. and Exbn. Petrotech, New Delhi, India.

Waples, D. W. (1985). Geochemistry in Petroleum Exploration (p. 232). Boston: D. Reidel Publishing Company. http://dx.doi.org/10.1007/978-94-009-5436-6

\section{Copyrights}

Copyright for this article is retained by the author(s), with first publication rights granted to the journal.

This is an open-access article distributed under the terms and conditions of the Creative Commons Attribution license (http://creativecommons.org/licenses/by/3.0/). 